\title{
Könyvszemle
}

SIPOS JÚLIA GONDOZÁSÁBAN

\section{SZEMPONTOK A FELELŐSSÉGTELJES ÉLETHEZ}

A reformáció jubileumi évében, 2017-ben jelent meg A protestáns etika kézikönyve címü terjedelmes és szép kiállítású kötet a Kálvin és a Luther Kiadó közös gondozásában. A többszerzős könyv fejezeteit protestáns (református és evangélikus) teológusok, társadalomtudósok írták. Fazakas Sándor szerkesztői munkáját dicséri, hogy a kötetbe olyan tanulmányokat válogatott be, amelyek valóban aktuális etikai, szociáletikai problémákról szólnak, és - amellett, hogy megfelelnek a tudományos elvárásoknak - a nem szakemberek (tehát nem teológusok és/vagy erkölcsi kérdésekkel foglalkozó kutatók) számára is befogadhatók. A szövegek jól áttekinthetők, több esettanulmány segíti az elméletek gyakorlati vonatkozásainak megértését, illetve áttekintő táblázatok is megkönnyítik az információk rendszerezését. A könyvben olvashatunk a beszéd és a képi megjelenítés etikájáról, a házasság, a család és a szexualitás vonatkozásában felmerülö erkölcsi kérdésekről, az élet kezdetének és végének etikai dilemmáiról, a környezethez, az új technológiákhoz és a gazdasági folyamatokhoz való viszonyunk morális alapú újragondolásának szükségességéről, a közélet és az erkölcs összefüggéseiről, az egyházi szolgálatok etikájáról, a reménység és a felelősség mibenlétéről. A felelősség fogalma nemcsak az utolsó fejezetben, Németh Tamás figyelemre méltó írásában kap szerepet, ez a kötet egyik kulcsfogalma, valamennyi témánál elökerül a felelős élet fontosságának hangsúlyozása. Fazakas Sándor az előszóban megfogalmazza: ,az etikai kompetenciák elsajátításához kíván segítséget nyújtani a könyv - ahhoz, hogy az ember legyen képes minden helyzetben mérlegelni, a szituációra reflektálni, a következményekkel számolni, s cselekedeteinek erkölcsi szempontból értékelhető irányultságot adni” (9.). Fazakas bevezető tanulmányában is kiemeli, hogy a feltétel nélküli engedelmességre való felszólítás helyett az érvelésen, a releváns szempontok felvetésén kell alapulnia a protestáns etikának, segítséget nyújtva az egyén felelősségteljes erkölcsi szemléletének kialakításához. Vallási értelemben kívülálló olvasóként - mivel nem tartozom egyik protestáns egyházhoz sem -, úgy vélem, hogy a szerkesztő elvárásai valóban teljesültek: a kötet szerzői természetesen meghatározott értékszemlélet alapján közelítik meg választott témájukat, de elsősorban gondolkodtatni akarnak, nem pedig megmásíthatatlan erkölcsi tantételeket rögzíteni. Ezt erősíti, hogy - bár a hivatkozások 
többsége a Szentírás (és olyan jelentős keresztény gondolkodók, mint Ágoston és Aquinói Tamás) mellett elsősorban Luther, Kálvin és más protestáns szerzők műveire történik - római katolikus szempontokat, pápai enciklikákat, intelmeket is figyelembe vett némelyik szerző, de bőven találhatunk nem vallási alapú etikai-filozófiai koncepciókra való utalásokat is.

A kötet oktatási (főként felsőoktatási) célokra is jól használható, bizonyos fejezetek írói kifejezetten tekintettel vannak erre, például a környezeti etikai részben az 1. esettanulmány után kérdéseket találunk (233.; a 2. esettanulmány leírását követően viszont már nincsenek kérdések, egyébként mindkét eset aktuális és releváns a téma szempontjából), a II. rész szerzője pedig azt írja, hogy a felhozott példákat szemináriumi órákon való megvitatásra szánja (54.). Számos fejezetben viszont nem találunk ilyen jellegủ utalásokat. Talán szerencsés lett volna egységesíteni a tanulmányokat ebböl a szempontból, például úgy, hogy a szerzők minden fejezet végén az olvasottak feldolgozását segítö kérdéseket tesznek fel, vagy valamennyien elhagyják az oktatási célú megjegyzéseket, kérdéseket. Nem túl szerencsés továbbá, hogy bizonyos fejezetek szerzői túl sok problémát vetnek fel, így fontos részkérdések érdemi kifejtésére nincs módjuk. Egyértelmü, hogy a kötetben közremüködők nem törekszenek/törekedhetnek témájuk kimerítésére, de néhol még így is kifogásolható az előbbi értelemben vett „túlzsúfoltság”. Különösen az élet kezdetének és végének kérdéseivel foglalkozó V. fejezetről mondható el, hogy a kötet terjedelméhez képest indokolatlanul röviden kerülnek tárgyalásra alapvető jelentőségü etikai problémák (az embrió státusza, eugenika, klónozás, eutanázia, asszisztált öngyilkosság, életvégi rendelkezések), alig valamivel több oldal jut e nehéz kérdések tárgyalására, mint a hazugság etikájának kifejtésére (II. fejezet). Nem az utóbbi rész hosszúságával van a baj - Visky S. Béla írása alapos és érdekes -, inkább az előző rövidségével, legalább két bővebb, különálló fejezetet (életkezdeti és életvégi dilemmák) kellett volna képezni. Mindenképpen kiemelendő ugyanakkor, hogy csak „,súlyozási” problémáim vannak, mivel az V. rész tartalmi szempontból a legkevésbé sem kifogásolható, Orosz Gábor Viktor nyilvánvalóan jártas a bioetikában. Talán az is magyarázhatja az életvégi etika rövid tárgyalását, hogy a közelmúltban, 2014-ben jelent meg az Ideje van az életnek, és ideje van a meghalásnak... címü, életvégi döntésekkel kapcsolatos keresztyén etikai tanulmányokat tartalmazó kötet, amelynek szerkesztője (Ferencz Árpád mellett) szintén Fazakas Sándor volt.

Végezetül néhány szó a még nem említett szerzők munkájáról. Rácsok Gabriella részben a „nézés” és a „látás” szembeállítására építi fel a képi megjelenítés etikájáról szóló írását: vizuális korunkban képek sokasága vesz körül bennünket, egyre többeken lesz úrrá a képkészítési és megosztási kényszer, és közben mintha elveszítettük volna a lényeges és a lényegtelen, a valóságos és a nem valóságos megkülönböztetésének képességét, ezért tudatosan tennünk kell azért, hogy „látóvá" váljunk. A házassággal, a családdal és a szexualitással kapcsolatos kérdéseket 
a szeretet, az intimitás és a hüség fogalmai mentén értelmezi Kovács Krisztián. Béres Tamás az ökoteológiáról és a természethez való viszonyunk átalakításának szükségességéról ír. Kodácsy Tamás szellemes tanulmányában öt bibliai technikai szimbólum - Ádám és Éva ágyékkötője a rejtőzködés, Noé bárkája az alkalmazkodás, Bábel téglája az építkezés, Mózes botja az irányítás, Péter és András hálója az együttmúködés szimbóluma - alapján technikai vívmányok (köztük a kvantumszámítógép és a 3D-nyomtatás) felhasználásának hatásait elemzi etikai szempontból. Szabó B. András a VIII. fejezetben - talán ez a rész is lehetett volna bővebb -, a protestáns gazdaságetikáról értekezik rövid, de lényeglátó munkájában. Színvonalas dolgozatokat olvashatunk továbbá a közélet és az egyházi szolgálatok etikájáról Borsi Attila, illetve Füsti-Molnár Szilveszter tollából.

Összességében megállapítható, hogy a könyv minden olyan protestáns szellemiségű ember számára ajánlható, aki saját etikai szemléletéhez elméleti megalapozást keres, de bárki találhat megfontolandó szempontokat a kötetben, amely remélhetőleg további erkölcsi diskurzusok kiindulópontjaként szolgálhat majd.

(Fazakas Sándor szerkesztö: A protestáns etika kézikönyve. Budapest: Kálvin Kiadó-Luther Kiadó, 2017, 460 o.)

Barcsi Tamás

egyetemi docens, Pécsi Tudományegyetem Egészségtudományi Kar 


\section{KANT-VITA, ÚJ FÉNYBEN}

Akárha egy irodalomtörténeti forráskiadást tartanánk a kezünkben. A „régi magyarosok" szoktak efféléket közzétenni. A magyar irodalom korpuszához tartozó, eredetileg latin nyelven írt és megjelent szöveget magyarra fordítanak, és a latin eredetivel együtt, a szükséges jegyzetekkel és mutatókkal fölszerelve, hozzáférhetővé teszik a mai olvasó számára.

Pedig ez most nem irodalomtörténeti, hanem filozófiatörténeti dokumentum. Rozgonyi József 1792-ben latinul megjelent antikantiánus vitairata, a kanti transzcendentális idealizmus ,alapvetéseiről” fogalmazott „,kétségek”, egyszerre számít ismert és ismeretlen munkának. A magyar filozófiatörténet fejlődésfolyamatának ismerői, egyrészt, persze, hallottak róla. Tudják, hogy ezzel a müvel indul meg a magyar filozófiatörténet híres összecsapása, a 18. század utolsó és a 19. század első két évtizedén keresztülívelö, azaz megszakításokkal jó harminc éven át tartó, úgynevezett „Kant-vita”. Olvasni viszont, másrészt, gyakorlatilag nem olvasta senki. A kérdés szakembereinek legszükebb körén kívül - ebbe a körbe kutatói nemzedékenként alig néhány fölkészült és elszánt érdeklődő tartozott - nemigen volt szokás kézbe venni: hogy voltaképp mi is szerepel benne, a kutatási hagyományban esetenként reflektálatlanul továbbadott információk tudósítottak róla.

Most pedig, az Akadémia Filozófiai Intézete Mester Béla vezette kutatócsoportjának köszönhetően, íme, itt van előttünk. A rendkívül elegáns kiállítású kötet fekvő téglalap alakú: az oldal fölső részén rendre a latin, alsó részén a magyar szöveg fut, a lapszéli hasábjába pedig a jegyzetek kerültek. Ez utóbbiakból meglehetősen sok van. Mint a kötet előszavának a kiadás elveit ismertető fejezete beszámol róla: a Dubia/Kétségek müfaja, nyelve és kora egyaránt sok jegyzetet indokol ugyanis. A müfaja vitairat: gondolatmenete a vitapartnerek müveinek szövegét követi, az olvasónak ezeket a szövegeket is célszerü nyomon követnie hát. A nyelve latin: a német nyelvü, kanti és a korai kantiánus szövegek latin szerzői interpretációja komoly és megmagyarázandó terminológiai kérdéseket vet föl, ezek megint magyarázatot igényelnek. A kora pedig a 18. század vége: idézési technikája gyakran nem szó szerinti, hanem tartalmi idézettel operál, a mai olvasó számára ezért ezeket az idézeteket is pontosítani kell.

A kiadás megoldásainak érdemi értékelése szakkritikába való. Kurta ismertetésünkben - a kiadás jelentőségét méltatandó - most csupán a lényegről tudunk beszélni.

Mi a lényeg? Rozgonyi József (1756-1823) protestáns peregrinus, losonci, majd sárospataki filozófiatanár, a reformkort közvetlenül megelőző időszak filozófusnemzedékének kiemelkedő alakja. Sárospataki tanulmányok után előbb Bécs- 
be megy, majd hosszabb tanulmányokat folytat Utrechtben, szemesztert hallgat Oxfordban, megfordul Párizsban, Göttingenben, Jénában és Halléban. Útravalóul két hatást hoz magával: az éppen megszülető kanti filozófia, illetve a korai Kant-viták ismeretét az egyik, a skót „,common sense” iskola szemléletét a másik oldalon. Losonci katedráját elfoglalva, pályakezdő filozófiai múvében, a Dubiában/Kétségekben épp ezt a kettőt kívánja ütköztetni: a skót iskola szellemében gyakorol határozott bírálatot a kanti ismeretfilozófia fölött. Latinul szerzett müve antikantiánus vitairat tehát.

Mindkét körülmény azonnal halálra is ítéli egyébként meglepően tájékozott és tiszteletreméltóan színvonalas munkáját. Mint éleslátó - nem mellesleg, saját hosszú kutatásainak eredményeit tömörítő - előszavában Mester Béla beszámol róla, a Dubia/Kétségek recepcióját épp ez a két tényező pecsételi meg: a nyelve és az irányzati beállítottsága. A mü tehát, egyrészt, éppen az előtt születik meg, hogy a tudományosság nyelvévé a nemzeti nyelv válna. Szerzője a nemzetközi tudományosság közegében, a nemzetközi tudományosság nyelvén szeretne megszólalni. Egy hatalmas nyelvi-kultúraszerkezeti váltás határán áll éppen. A nemzeti nyelv kialakulásával és a nemzeti kultúra-tudományosság intézményesülésével törekvése hamarosan idejétmúltnak hat. A magyar filozófia történetírása ráadásul - fontos szempont - a régi magyar filozófiát is hajlamos reflektálatlanul azonosítani a magyar nyelvü filozófiával. Mintha, hogy analóg német példát hozzunk, a latinul és franciául író - németül csupán rövidebb politikai érdekủ esszéit fogalmazó - Leibnizet nem számítanánk német filozófusnak; vagy, még közelebbi példával, Kant latin nyelvü prekritikai írásait nem tekintenénk a kanti életmü és a német filozófia részének. A mủ ugyanakkor, másrészt, a Kant-vita kontribúciójaként, sőt éppen elindítójaként: antikantiánus értekezés. A meggyökeresedett filozófiatörténeti hagyomány szerint a Kant-vita a Kant-recepció meghatározó hullámaként fogható föl. Valóban: ez a több évtizedes nézetcsere lesz az, amely a kantianizmust szélesebb körben elterjeszti a magyar gondolkodásban; átfogóbban, jó évszázadra a kantianizmust emeli a magyar filozófia fóáramává. Szerzőnk ehhez képest nem az „egyik”, hanem a „másik” oldalon áll: nem a kanti gondolatok befogadásán munkálkodik, hanem éppen a kantianizmus bírálatában érdekelt. A kantianizmus vezető árama ellenében: éppen antikantiánus.

Tanulságok? Az egyik, szükebben, a Kant-vitáról formált képünket illeti; a másik, tágabban, a recepciótörténetként fölfogott magyar filozófiatörténet problémájára vonatkozik.

Egyfelől tehát, a kitűnő kiadvány nyomán némiképp új fénybe kerül a hagyományos kép, amelyet a Kant-vitáról őrzünk. Eszerint, úgymond, a Kant-vita legfontosabb vonása az autonóm filozófiai közeg hiánya, illetve a keretében kirajzolódó Kant-kép reduktív jellege. A német egyetemeket megjárt, a kantianizmussal megismerkedett protestáns paptanárok vitája tehát filozófiai vita 
akkor, amikor még nincs filozófiai élet. A filozófiai gondolatok recepciójának ezért nincs önálló szférája, a befogadást így más dimenziók - elsősorban a politika és az erkölcs - határozzák meg. Mindezek következtében pedig a kanti életmű egyszerűsítésnek esik áldozatul: a vitában megjelenő Kant etikai-teológiai gondolkodó lesz csupán. Hogy a kritikai filozófia ismeretfilozófiai-logikai rétege genetikusan és strukturálisan is megelőzi az etikai-világnézeti réteget, ezzel a vitázók alig-alig vetnek számot. Az ismerős - korábbi kísérleteinkben magunk által is elfogadott - kép most némiképp más árnyalatban tünik föl. A Kant-vita igenis, eredetileg sajátképpen filozófiai vitának indul: Rozgonyi éppen a nemzetközi tudományos közösség előtt vállalkozik rá, hogy vitatni kezdje a kanti filozófiát. És a vitában megformálódni kezdő Kant-kép igenis, eredetileg a kanti bölcselet „mélyfilozófiai”-ismeretfilozófiai rétegét teszi diszkusszió tárgyává.

Másfelől, átfogóbban, érdemes elgondolkodnunk a magyar filozófia recepciótörténeti jellegén. Eszerint, ugye, a magyar filozófia voltaképpen idegen-nyugati filozófiák befogadásában áll. A magyar filozófia először skolasztikus filozófia, aztán befogadja előbb a kartezianizmust, majd a kantianizmust és a hegelianizmust, aztán a szellemtörténetet, utána a marxizmust, hogy mára a különféle kortársi irányok - az analitikus filozófia, a hermeneutika meg a posztmodern - befogadásával kísérletezzen. A nyugati irányok itteni hatásának történeteként fölfogott magyar filozófiatörténet kutatói pedig ezért hagyományosan a recepció élénkségén-gyorsaságán, illetve önállóságán-eredetiségén mérik egy-egy hazai filozófiai teljesítmény jelentőségét. A kánonban az szerepel előkelőbb helyen, aki hamarabb és alkotóbban fordul az éppen új felé. A 18. század végének és 19. század első felének két nagyszabású szellemi összecsapásában, a Kant-vitában is és a Hegel-vitában is, az „új” meg a „régi” vitázik, a ,jövőbe mutató” meg a „múlthoz tartozó” gondolkodók küzdenek meg egymással - az előbbiek valahogyan a jók, a jelentősek, az utóbbiak ellenben a rosszak, a gondolatilag is jelentéktelenek. Jelen kötettel Mester Béla most azt bizonyítja nekünk, hogy ez a szembeállítás nem föltétlenül állja meg a helyét; előfordulhat, hogy a „régihez” ragaszkodó meg a „múlthoz tartozó” gondolkodók, mint Rozgonyi esete mutatja, bizony jelentősebbek haladó vitapartnereiknél.

A kiadvány a filozófiai intézetnek a „magyar filozófiatörténet narratíváit” földolgozó, nagyszabású OTKA-kutatása keretében született meg. Párdarabja, Szontagh Gusztáv önéletrajza - azt a kötetet is lesz szerencsénk itt ismertetni hasonlóképp ennek a kutatásnak köszönheti megjelenését. Ha az a Hegel-vita árnyékos alakját jelenítette meg nekünk, ez a mostani kötet a Kant-vita negatív hősét igyekszik rehabilitálni. A két kötettel Mester Béla mintha, lassan és finoman, újrarajzolná a 18. század végi, 19. századi magyar filozófiáról alkotott képünket. 
(Josephi Rozgonyi: Dubia de initiis transcendentalis idealismi Kantiani; Rozgonyi József: Kétségek a kanti transzcendentális idealizmus alapvetéseivel kapcsolatban. Forditotta: Guba Ágoston; a jegyzeteket összeállitotta: Guba ÁgostonMester Béla; a forditást az eredetivel egybevetette: Kondákor Szabolcs; a latin szöveg sajtó alá rendezésében részt vett: Gángó Gábor. [Ergo], Budapest: MTA Bölcsészettudományi Kutatóközpont, Filozófiai Intézet-Gondolat Kiadó, 2017.)

Perecz László

filozófiatörténész 